e-ISSN. 2685-7650

Vol. 1 No. 2 (2019), pp 90-106

DOI: https://doi.org/10.33366/jkn.v1i2.25

\title{
Memperkokoh Posisi Tawar Politik Pegiat Sistem Penyediaan Air Minum Berbasis Masyarakat Lewat Komunikasi Lingkungan
}

\author{
Rochmad Effendy, ${ }^{1}$ Rofikul Amin, ${ }^{2}$ Ginanjar Indra Kusuma ${ }^{3}$ \\ ${ }^{1}$ Program Studi Ilmu Komunikasi, Universitas Merdeka Malang \\ ${ }^{2}$ Program Studi Manajemen, Universitas Merdeka Malang \\ ${ }^{3}$ Program Studi Adminstrasi Bisnis, Universitas Merdeka Malang \\ Email: rochmad.effendy@unmer.ac.id
}

\begin{abstract}
The limited ability in providing a good water services to all citizens, as well as the fact that water is a public good, the involvement of citizens in drinking water supply is one way to achieve this goal. The existence of a community-based drinking water supply system in the form of the Community Drinking Water User Association (HIPPAM) needs to be maintained to ensure the sustainability of its social services. The sustainability of the HIPPAM social enterprise is determined by internal aspects such as governance and institutional performance, financial management, technical performance of water distribution services. Other things related to external aspects such as the support of stakeholders such as customers, community members, environment activist and village government related to the issue of conservation as well as environmental sustainability and good water governance. Discussing these issues with all stakeholders in drinking water in the available local public space can be referred to as environmental communication that is hoped will be able to create awareness and citizen's collective action citizens on the importance of good water governance. This study uses qualitative data with interviews and in-depth interviews as data collection techniques, the informants of this study consisted of the management of the HIPPAM Mangga Dua. The result showed that administrators had sufficient environmental and ecological literacy. For them, water is spiritual and social energy sources that enable them to develop dan enhance the community's social capital.
\end{abstract}

Keywords: Community Based Water Supply System, Association Drinking Water Users, Good water governance, Co Management, Environmental Communication, Sustainable Development.

\begin{abstract}
Abstrak: Keterbatasan kemampuan negara dalam menyediakan layanan air bersih kepada seluruh warga masyarakat, serta fakta bahwa air merupakan barang publik, maka keterlibatan warga masyarakat dalam penyediaan air minum merupakan salah satu cara untuk mencapai tujuan tersebut. Keberadaan sistem penyediaan air minum berbasis masyarakat berupa Himpunan Penduduk Pemakai Air Minum (HIPPAM) perlu untuk terus dipelihara untuk menjamin keberlangsungan jasa sosial layanannya. Sustainability (keberlangsungan) usaha sosial HIPPAM ini ditentukan oleh aspek-aspek internal seperti tata kelola dan kinerja kelembagaan, manajemen keuangan, kinerja teknis layanan distribusi air. Hal lain terkait dengan aspek eksternal seperti dukungan para pemangku kepentingan seperti pelanggan, warga masyarakat, perangkat lingkungan dan pemerintahan desa terkait dengan isu konservasi serta ramah lingkungan hidup dan tata kelola air yang baik (good water governance). Memperbincangkan isu-isu tersebut bersama seluruh pemegang kepentingan air minum pada ruang publik lokal yang tersedia dapat disebut sebagai komunikasi lingkungan, yang diharapkan mampu menciptakan kesadaran dan tindakan kolektif warga tentang pentingnya tata kelola air yang baik (Good water governance). Penelitian ini mengunakan pendekatan kualitatif dengan pengamatan berperan dan wawancara mendalam sebagai teknik pengumpulan data, informan penelitian ini terdari dari pengurus HIPPAM Mangga Dua. Hasil dari penelitian menunjukkan bahwa para pengurus telah memiliki literasi lingkungan dan literasi ekologis yang mencukupi. Air bagi mereka sumber energi spiritual dan sosial yang mampu menggerakkan modal sosial masyarakat.
\end{abstract}

Kata Kunci: Sistem Penyediaan Air Minum Berbasis Masyarakat, Himpunan Penduduk Pemakai Air Minum, Good water goverrnance, Co Management, Komunikasi Lingkungan, Pembangunan berkelanjutan. 


\section{Jurnal Komunikasi Nusantara}

e-ISSN. 2685-7650

Vol. 1 No. 2 (2019), pp 90-106

DOI: https://doi.org/10.33366/jkn.v1i2.25

\section{Pendahuluan}

Undang Undang Dasar Republik Indonesia pasal 33 telah menetapkan air, bumi dan segala yang terkandung di dalamnya dikuasai oleh negara untuk dimanfaatkan sebesar-besarnya bagi kemanfaatkan rakyat. Penguasaan air oleh negara dimaksudkan agar air yang merupakan benda publik (public goods) dapat memberikan manfaat kepada semua warga negara secara adil. Merupakan commons (barang milik bersama), air tidak boleh dimiliki dan dikuasai oleh pelaku non-negara. Kalau dilepas bebas kepemilikan bersama ini, akan memunculkan apa yang disebut Garreth Hardin (1968: 1244) sebagai tragedy of commons (tragedi kepemilikan bersama) "freedom in commons brings ruin to all'. Sumber daya air, makanya harus dikelola secara bersama-sama antara pemerintah, swasta dan warga masyarakat. Untuk menjamin ketersediaan layanan air bersih yang aman kepada masyarakat terutama di pedesaan, pemerintah dengan bantuan lembaga donor internasional telah meluncurkan program sistem penyedian air minum berbasis masyarakat. Program ini seperti Water and Sanitation for Low Income Communities (WSLIC) 1 dan 2 dan program Penyediaan Air Minum dan Sanitasi Berbasis Masyarakat (PAMSIMAS) tahap 1 dan 2. Kemudian ditambah dengan Sistem penyediaan air minum berbasis masyarakat di luar kedua program tersebut. Data CPRG (2018:2) mencatat 12.254 sistem air berbasis masyarakat lewat PAMSIMAS dengan jumlah 15,6 juta penduduk yang tersebar di 33 provinsi dan 365 Kabupaten. Pemerintah menargetkan membangun 20.000 SPAM, dengan target 22,1 juta jiwa pada tahun 2020. Ini sejalan dengan RPJMN 2015-2019 yang mentargetkan 60 persen penduduk akan dilayani lewat SPAM dan sisanya akan terlayani melalui sistem perpipaan PDAM.

Meski demikian masalah beberapa masalah baik internal maupun eksternal menimpa SPAM. Kalau tidak tertangani, masalah tersebut akan mengancam keberlangsungan layanan air minum berbasis masyarakat. Al'Afghani, et.al (2019: 289) memaparkan ada empat masalah yang biasa dialami SPAM , yakni (i) belum memiliki status lembaga hukum yang pasti (ii) standar layanan yang tidak jelas, (iii) kurangnya keamanan aset, dan (iv) keamanan finansial yang terbatas. Sedangkan masalah eksternal adalalah ketersediaan sumber daya air yang terkait dengan kesadaran dan komitmen warga masyarakat untuk berperilaku ramah lingkungan dan konservasi lingkungan hidup. Hal lainnya mencakup regulasi perundangan air. Dengan diberlakukannya UU No 172019 Tentang Sumber Daya Air yang menurut para pegiat lingkungan hidup dan masyarakat sipil akan mengancam keberlangsungan SPAM. Ini akbiat nuansa swastanisasi, serta pengabaian aspek ekologis sumber daya air dan masyarakat hukum adat (CNN Indonesia); (Inews, Rabu, 18 September 2019); (Koran Tempo, 21 September 2019); (Tirto.id., 31 Agustus 2019) : (Kumparan News, 19 September 2019). Untuk itu, penelitian kualitatif ini berusaha memotret bagaimana wacana diskursus ramah lingkungan, konservasi sumber daya alam, pandangan tentang esensi air diperbincangkan dan dikomunikasikan oleh para pengurus HIPPAM Mangga Dua Wonokerso Pakisaji Kabupaten Malang: bagaimana tindakan komunikasi lingkungan terjadi di antara warga, pengurus HIPPAM dan para pemegang kepentingan yang lain.

\section{Kesalingketerkaitan Air, Mahluk Hidup dan Alam Semesta}

Segala sesuatu yang berada dalam Alam Semesta (Nature), menurut Bartholomew (2010: 271-2) merupakan sebuah kesatuan tunggal atau satu. Air, makanya sebagai salah unsur alam semesta dianggap sumber kesadaraan dan mediator spiritual terhadap kesatupaduan Alam Semesta ini. Air merupakan penciri umum dari semua mahluk hidup, media komunikasi dalam dan antara organisme. 


\section{Jurnal Komunikasi Nusantara}

e-ISSN. 2685-7650

Vol. 1 No. 2 (2019), pp 90-106

DOI: https://doi.org/10.33366/jkn.v1i2.25

Melalui air jejaring kehidupan yang rumit dan kompleks ditata, diatur sedemikian rupa sehingga tercipta saling ketergantungan antara semua bentuk mahluk hidup. Bartholomew (2010: 266), makanya memandang air sebagai model sebuah kesatupaduan (holism) kehidupan yang berkelanjutan. Keberlanjutan disini harus dimaknai sebagai sebuah organisme yang memiliki sistem yang berkelanjutan yang memungkinnya untuk menjaga semua energi dalam sebuah keseluruhan yang menciptakan keseimbangan; surplus energi dari satu bagian organisme akan digunakan oleh bagian yang lain.

Kehidupan yang berkelanjutan berarti menerapkan secara nyata prinsip dasar ekologi yang menurut Capra (1994:10) terdiri kesaling tergantungan, daur ulang, kerjasama, fleksibilitas, dan keberagaman (interdependence, recycling, partnership, flexibility, diversity). berpikir dalam Kerangka sistem yang kompleks, makanya menjadi keniscayaan sejarah agar tercapai kehidupan manusia yang berkelanjutan. Capra (2007:11-12) memandang kerangka pikir ini meniscayakan untuk memandang dunia secara holistik (keseluruhan); masing-masing unsur mahluk hidup dan alam dalan kerangka keterkaitan, saling terhubungan dan konteks. Terobosan berpikir radikal tersebut adalah: dari bagianbagian kepada keseluruhan (From the parts to the whole); dari memandang alam sebagai objek material kepada kesaling keterkaitan (From objects to relationships); dari pengetahun objektif kepada pengetahuan kontekstual ; dari kuantitas kepada kualitas. Singkat kata, sistem hidup dan kehidupan itu non-linear alias terkait satu dengan yang lain. Bertentangan dengan tradisi berpikir modern yang berada dalam kerangka berpikir linear yang memandang sesuatu semata-mata dalam kerangka rangkain sebab akibat. Berdasarkan Teori Quantum, Capra (1975:68) menegaskan adanya kesatuan dasar alam semesta. Ini berarti semua unsur alam semesta, termasuk mahluk hidup saling terikat dan terkait satu dengan dengan unsur yang lain sebagai jaringan hubungan rumit antara berbagai bagian dari keseluruhan.

\section{Pengertian Komunikasi Lingkungan dan Kommunikasi Pembangunan}

Isu utama dalam komunikasi lingkungan adalah bagaimana memelihara harmoni ekologis antara manusia dengan lingkungannya untuk mewujudkan pembangunan yang keberlanjutan. Ini selanjutnya akan bermuara pada perubahan sikap dan perilaku sosial masyarakat yang ramah terhadap lingkungan. Bersinggungan erat dengan pembangunan, komunikasi lingkungan dapat menjadi bagian dari komunikasi pembangunan untuk perubahan sosial (Development Communication for Social Change). Komunikasi lingkungan menurut Lie \& Serveas (2015: 2510) berupaya mengkaji semua interaksi manusia dengan lingkungan dan merupakan sub-disiplin yang relatif baru dalam ilmu komunikasi. Komunikasi lingkungan tidak hanya mencakup pengelolaan lingkungan, tetapi juga studi tentang opini dan persepsi publik. Hal ini, makanya terkait erat dengan dengan pendidikan. Ruang lingkup Komuling mencakup membangun kepedulian masyarakat terhadap lingkungan hidup (Wahyudin, 2017); (Bakti, Iriana., et.al 2017) ; mitigasi bencana erupsi gunung api, konnservasi laut dan pengelolaan sumber daya alam (Lestari, et.al : 2016) ; (Swarnawati, 2018); (Ardian,, 2019).

Komunikasi lingkungan dan pendidikan lingkungan terkadang tumpang tindih, terutama ketika istilah-istilah tersebut digunakan di luar lingkup akademis dalam domain publik. Komunikasi untuk pembangunan berkelanjutan menekankan pada aspek keberlanjutan interaksi; manusia dengan manusia dan manusia dengan alam lingkungannya. Kedudukan sentral komunikasi lingkungan dapat dijelaskan dengan premis bahwa keberlangsungan manusia dan alam telah menjadi tema penting dalam kegiatan pembangunan dan perubahan sosial. Intervensi yang berkesinambungan makanya perlu dilakukan untuk memastikan bahwa tata kehidupan dunia layak bagi generasi mendatang. Untuk itu, pendekatan ekonomi politik saja tidak mencukupi tapi juga harus dilengkapi dengan dengan 


\section{Jurnal Komunikasi Nusantara}

e-ISSN. 2685-7650

Vol. 1 No. 2 (2019), pp 90-106

DOI: https://doi.org/10.33366/jkn.v1i2.25

pendekatan sosial budaya demi menjamin tercapainya derajat keberlanjutan yang terpadu serta terbangunnya ketahanan masyarakat. Tidak heran kalau, membangun komunitas yang tangguh adalah isu prioritas dalam bidang Komunikasi Pembangunan untuk Perubahan Sosial. Ini berarti sebuah langkah terobosan baru menjauh dari modernisasi yang tidak ramah lingkungan, menuju kepada penekanan pada sistem kearifan lokal yang mengalihkan orientasi pembangunan yang bernuansa Barat dengan mengutamakan budaya dan partisipasi lokal menjadi prioritas penting untuk memahami pembangunan berkelanjutan (Lie \& Serveas: 2015: 253).

Pembangunan berkelanjutan menjadi agenda utama seluruh negara sejak diluncurkannya laporan Brundtland bertajuk "Our Common Future" (1987) dan diselenggarakannya Konferensi PBB tentang Lingkungan dan Pembangunan di Rio de Janeiro (1992). Hal tersebut meniscayakan adanya keseimbangan antara pertumbuhan ekonomi, keadilan sosial, dan alam lingkungan hidup. Sebuah model pembangunan manusia yang menekankan pada kemandirian diri dan hubungan ekologis harmonis antara manusia, alam dan teknologi; antara individu dengan manusia lain; pendekatan makra dan makro; perencanaan dan otonomi pembangunan; antara negara dengan masyarakat sipil menjadi sebuah keniscayaan dalam memberdayakan kelompok masyarakat beserta aktor sosial masyarakat. Isu utama di sini adalah bagaimana memberikan peluang seluas-luasnya kepada warga masyarakat yang terpinggirkan dengan beragam latar belakang sosial budaya mereka untuk dapat mengatur, mempertahankan dan mengembangkan inisiatif membangun dari persepktif mereka sendiri (Lie \& Serveas: 2015: 251).

Peran sentral komunikasi lingkungan dapat dijelaskan pada fakta bahwa manajemen sumber daya alam adalah disiplin yang berhubungan dengan bagaimana mengelola, mengawasi, dan menata air, tanah, hewan, dan tanaman. Manajemen sumber daya alam yang berkelanjutan berupaya mencari derajat keseimbangan antara pertumbuhan ekonomi dan kualitas hidup dan mutu lingkungan hidup. Ini lantas melahirkan manajemen adaptif yang mencakup masalah-masalah seperti manajemen informasi dan pengetahuan, pemantauan dan evaluasi, dan manajemen risiko. Agar terwujud keberlanjutan pembangunan, papar Lie \& Serveas (2015: 252), diperlukan sebuah pengelolaan sumber daya alam terpadu (Integrated Natural Resources Manajement) yang mencoba menyatukan manajemen adaptif bersama dengan perencanaan partisipatif dan partisipasi penuh masyarakat. Hal ini meniscayakan adanya pengelolaan sumber daya alam yang berbasis komunitas, manajemen bersama atau berbagi tata kelola sumber daya alam antara negara dengan warga komunitas (co-management), dan analisis berbasis pada multi pemangku kepentingan.

Di samping itu, letak pentingnya komunikasi lingkungan juga terlihat pada fakta bahwa manajemen sumber daya alam seringkali melibatkan masalah kelompok pemangku kepentingan, serta tindakan dan proses pembelajaran sosial multi-pemangku kepentingan. Bahkan akhir-akhir ini, peneliti manajemen sumber daya alam telah mulai menggunakan teori dan model dari analisis jejaring sosial (social network analysis) untuk meneguhkan argument akan pentingnya komunikasi dan struktur jaringan. Analisis jaringan yang biasanya terjadi dalam konteks komunikasi antar pribadi makanya menjadi pendekatan yang penting untuk memperkuat hubungan jaringan sosial (Lie \& Serveas: 2015: 252). Hal ini mengingat bahwa permasalahan pembangunan termasuk di dalamnya lingkungan hidup sangat kompleks yang makanya memerlukan keterlibatan semua pemangku kepentingan untuk berdialog dan mengkomunikasikan isu-isu tersebut.

\section{Definisi Komunikasi Lingkungan}




\section{Jurnal Komunikasi Nusantara}

e-ISSN. 2685-7650

Vol. 1 No. 2 (2019), pp 90-106

DOI: https://doi.org/10.33366/jkn.v1i2.25

Pezzullo \& Cox, Robert (2018:13) memaknai komunikasi lingkungan sebagai cara ekspresi pragmatis dan konstitutif berkaitan dengan penamaan, pembentukan, orientasi, dan negosiasi tentang dari bagaimana menjalin hubungan ekologis dengan lingkungannya termasuk y dengan sistem, elemen, dan spesies yang bukan manusia. Pragmatis di sini terdiri dari cara interaksi verbal dan nonverbal untuk menyampaikan tujuan instrumental. Komunikasi pragmatis menyambut, menginformasikan, menuntut, berjanji, meminta, mendidik, mengingatkan, membujuk, menolak, dan banyak lagi. Sedangkan konstitutif adalah melibatkan cara berinteraksi verbal dan nonverbal yang bermaksud membentuk, mengorientasikan, dan menegosiasikan makna, nilai, dan hubungan. Komunikasi konstitutif dimaksudkan untuk memantik perspektif tertentu, membangkitkan kepercayaan dan perasaan tertentu, serta memupuk cara-cara khusus berhubungan dengan orang lain.

Sementara itu Jurin, et.al (2010:13) memaknainya sebagai studi tentang cara manusia berkomunikasi tentang lingkungan, efek komunikasi ini pada persepsi manusia tentang lingkungan dan diri mereka sendiri, dan hubungannya dengan lingkungan hidup. Hal ini dapat dicapai lewat cara pragmatis dan konstitutif untuk meningkatkan pemahaman manusia tentang lingkungan serta hubungannya dengan dunia alami. Ini, makanya berkatian dengan cara pengungkapan simbolis yang digunakan meningkatkan pemahaman terhadap masalah lingkungan dan menegosiasikan berbagai tanggapan masyarakat tentang masalah tersebut. Mengutip Meisner (2008: 12) Jurin et.al mendefinisikannya sebagai semua bentuk komunikasi antar pribadi, kelompok, publik, organisasi dan media massa yang menimbulkan debat dan diskusi sosial tentang isu-isu dan hubungan manusia dengan lingkungannya. Menyitir pendapat Corbett JB (2006) Jurin.et.al (2008: 14) memaknai komunikasi lingkungan biasanya kegiatan komunikasi yang : Dinyatakan dalam nilai, kata, tindakan, dan praktik sehari-hari ; Ditafsirkan dan dinegosiasikan secara individual ; Berakar secara historis dan budaya serta didorong secara ideologis; Tertanam dalam paradigma sosial dominan yang memberikan nilai instrumental pada lingkungan dan meyakini keberadaannya untuk melayani manusia. Jurin.et.al (2008:15) lantas menawarkan sebuah pengertian komprehensif tentang komunikasi lingkungan yakni: the systematic generation and exchange of humans' messages in, from, for, and about the world around us and our interactions with it. (Proses menciptakan dan mempertukarkan pesan-pesan humanis secara sistematis di dalam, dari, untuk dan tentang lingkungan sekitar kita serta interaksi kita dengan lingkungan hidup). Definisi yang adalah seperti dipaparkan oleh Flor (2004:4) yakni menerapkan pendekatan, prinsip, strategi dan teknik komunikasi untuk tujuan mengelola dan memelihara dan melindungi lingkungan hidup. Ini adalah proses pertukaran informasi, pengetahuan, kebijakan tentang lingkungan hidup. Komunikasi ini diperlukan bagi keberlangsungan setiap sistem mahluk hidup baik yang berupa organisme, sistem ekologi, atau sistem sosial. Keterkaitan antar semua mahluk hidup dengan lingkungannya, Komunkasi lingungan memandang bahwa tujuan komunikasi manusia itu adalah mencapai saling memahami. KL merupakan bagian terpadu tak terpisahkan dari pengelolaan lingkungan hidup. KL bukan hanya berorientasi pada sumber atau media-sentris, tapi juga harus memungkinkan partisipasi publik yang lebih besar. Bahkan, harus memungkinkan dan memberdayakan audiens untuk tidak tetap sebagai penerima pasif tetapi menjadi sumber informasi yang aktif juga. Singkat kata, Komunikasi Lingkungan menurut The International Environmental Association (THEIECA) (2008:1) adalah kegiatan komunikasi tentang isu-isu lingkungan hidup yang juga merupakan kajian lintas disiplin ilmu yang berupaya untuk membahas peran, teknik serta pengaruh komunikasi terhadap permasalahan lingkungan hidup.

\section{Model Komunikasi Lingkungan}




\section{Jurnal Komunikasi Nusantara}

e-ISSN. 2685-7650

Vol. 1 No. 2 (2019), pp 90-106

DOI: https://doi.org/10.33366/jkn.v1i2.25

Model komunikasi lingkungan ada dua. Pertama, lebih menekan pada konteks komunikasi antar pribadi yang bertujuan memaksimalkan proses pertukaran dan interaksi langsung. Dengan demikian, model yang tepat menurut Flor (2004: 16) adalah model komunikasi konvergensi (Figure 3 1) yang memandang komunikasi sebagai rangkaian siklus dan bersifat interaktif. Model ini, makanya tidak membedakan antara sumber dan penerima, demikian juga antara pesan dengan umpan balik; keduanya dipandang memiliki kedudukan sejajar.

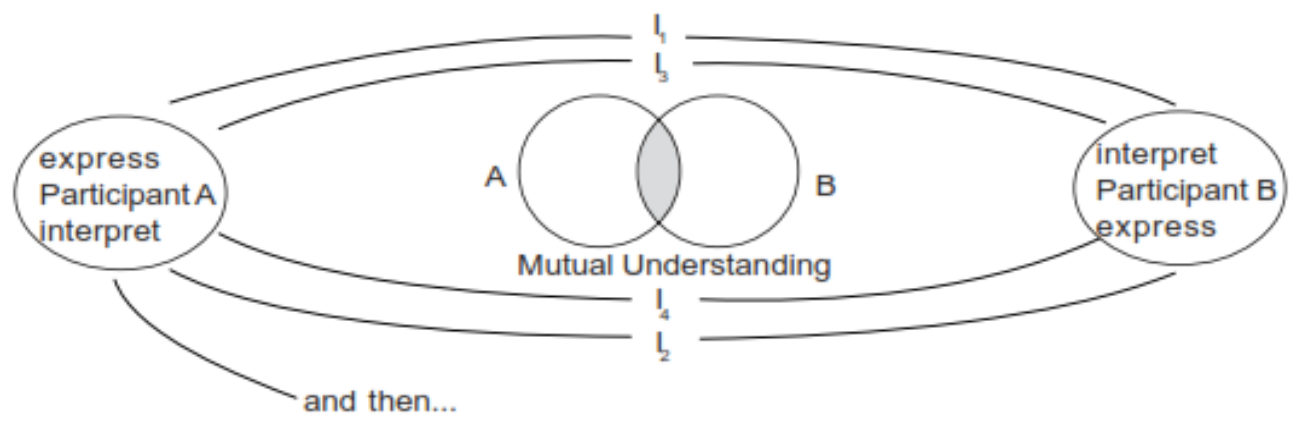

Figure 3-I. The convergence model of communication

Gambar 1 : Model Komunikasi Konvergensi

Sumber : Flor, G., Alexander., 2004, Environmental Communication : Principles, Approaches and Strategies of Communication : Applied to Environmental Management

Sama dengan yang pertama, model kedua juga menekankan pada konteks komunikasi antar pribadi. Hal ini adalah model ekologis proses komunikasi (Ecological Model of the Communication Process). Ini mengingat komunikasi lingkungan biasanya terjadi pada konteks jejaring sosial dengan memanfaatkan komunikasi antar pribadi. Kerangka model yang ditawarkan Foulger (2004) ini, memandang komunikasi sebagai proses pembentukan pesan antara pencipta-konsumen pesan-pesan antara kedua belah pihak. Memindahkan sebuah pesan kepada pikiran pihak lain membutuhkan bahasa dan media. Hubungan antara pencipta dan konsumen bersifat dinamis, siklus, dan beragam karena makna dibentuk, disalingpertukarikan, dan ditanggapi secara bersamaan oleh kedua belah pihak. Penciptaan dan konsumsi pesan terjadi bersama-sama, seringkali secara bersamaan pada diri individu bersangkutan. Kunci utama untuk memahami model ini adalah konsep instantiation 'Instansiasi, menerjemahkan sesuatu abstrak menjadi yang konkret dan nyata. Makna memang dimulai dari dalam pikiran seseorang yang masih abstrak alias belum konkrit sampai ia mengungkapkannya lewat pemanfaatan bahasa dan media. Sebagai pembuat pesan, orang tersebut telah mampu mengalihkan ide-ide abstraknya menjadi nyata. Model ini secara grafis dapat dilihat dari gambar berikut ini. 
e-ISSN. 2685-7650

Vol. 1 No. 2 (2019), pp 90-106

DOI: https://doi.org/10.33366/jkn.v1i2.25

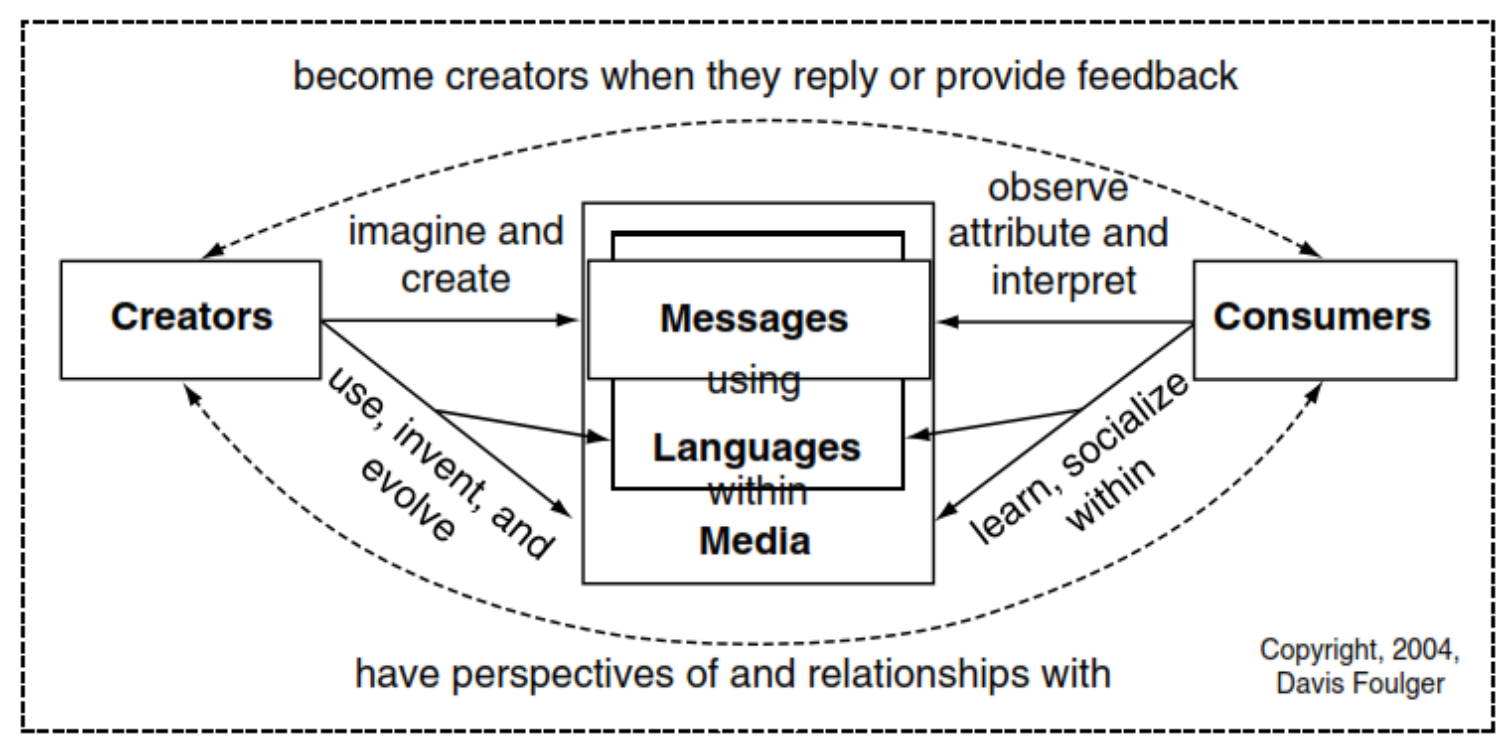

Gambar 2: Ecological Model of the Communication Process

(sumber: Foulger, Davis (2004) An ecological model of the communication process)

\section{Literasi Lingkungan (Environmental Literacy) dan Literasi Ekologis}

Lewat perkembangan pesat bidang ilmu pengetahuan dan teknologi, perilaku kehidupan manusia modern saat ini berdampak terhadap keseluruhan ekologi planet. Ini yang melatarbelakangi pentingnya Literasi lingkungan yang ditambah dengan beban tanggungjawab untuk pemulihan, konservasi, dan keberlanjutan. Tanggung jawab ini mencakup hubungan timbal balik antara manusia dengan lingkungan. Seseorang yang berwawasan lingkungan mampu memahami dan menafsirkan kesehatan relatif sistem lingkungan kemudian mengambil tindakan yang tepat untuk memelihara, memulihkan, dan meningkatkan kesehatan sistem tersebut. Melek lingkungan Menurut Jurin et.al (2010: 45) ini dapat diukur lewat beberapa indikator : (1) Pengetahuan tentang isu-isu lingkungan dan ilmu yang dapat dipercaya di belakangnya ; (2) Memahami 'seluruh gambar' 'whole picture' bukan gambar terpotong-potong tentang lingkungan hidup alias alam semesta ; (3) Empati terhadap lingkungan secara keseluruhan; (4) Memiliki keyakinan, nilai, dan sikap yang bertanggung jawab terhadap keseimbangan lingkungan ; (5) Keterlibatan aktif dalam memecahkan masalah lingkungan. Dengan kata lain, Literasi lingkungan hidup menurut McBride (2013:3) terdiri dari kesadaran dan keprihatinan tentang lingkungan beserta permasalahan yang menyertainya dan pengetahuan, ketrampilan serta motivasi untuk berupaya menyelesaikan permasalahan lingkungan saat ini dan mencegah terjadinya permasalahan lingkungan.

Berbeda dengan literasi lingkungan, literasi ekologis (Ecological literacy) lebih menekankan pada pentingnya untuk menambahkan berpikir sistem pada literasi lingkungan. Ini berarti kemampuan untuk memahami kompleksitas yang interaktif dari sistem lingkungan hidup; prinsip-prinsip tatanan ekosistem dan penerapannya beserta bagaimana hal ini akan mempengaruhi kegiatan pembangunan manusia yang berkelanjutan; bagaimana berpikir secara holisitik dan terintegrasi pada semua tingkatan tindakan, sikap dan perilaku manusia ; kesaling tergantungan dan interaksi antar semua komponan dalam alam semesta Jurin et.al (2010: 45). 


\section{Jurnal Komunikasi Nusantara}

e-ISSN. 2685-7650

Vol. 1 No. 2 (2019), pp 90-106

DOI: https://doi.org/10.33366/jkn.v1i2.25

\section{Metode Penelitian}

Penelitian ini dilakukan pada HIPPAM Mangga Dua Desa Wonokerso Pakisaji Kabupaten Malang. Mengunakan pendekatan kualitatif dengan pengamatan berperan dan wawancara mendalam sebagai teknik pengumpulan data, informan penelitian ini terdari dari pengurus HIPPAM Mangga Dua; Suhadi (Ketua), Bambang Wiyono (Sekretaris); Mulyono ( Pengawas); Muslimin (Pencatat Meteran); konsumen ( Lilis ) dan Ketua Asosiasi HIPPAM Kota Malang Adi Arif Rendra.

\section{Hasil dan Pembahasan \\ PNPM-MP Pendorong Lahirnya HIPPAM}

Program Nasional Pemberdayaan Masyarakat Mandiri Perkotaan (PNPM-MP) yang merupakan program penanggulan kemiskinan menerapkan pendekatan pembangunan berbasis masyarakat (community based/driven development). Program ini memandang masyarakat sebagai pelaku utama pembangunan; mengetahui apa yang terbaik untuk menyelesaikan permasalahan mereka berdasarkan persektif nilai-nilai dan pranata sosial yang dimiliki. Agar kemiskinan dapat ditanggulangi, nilai-nilai kebaikan seperti kejujuran, kepedulian, kejujuran, pengorbanan, keikhlasan harus diwujudkan dalam perilaku masyarakat. Penyebab utama kemiskinan, menurut PNPM adalah lunturnya dan belum mewujudnya perilaku kebaikan di masyarakat, bukan sebab lain seperti terbatasnya akses masyarakat terhadap modal ekonomi atau rendahnya tingkat pendidikan. Nilai-nilai moral tersebut harus menjiwai semua rangkaian manajemen program mulai dari perencanaan, pelaksanaan, monitoring hingga evaluasi (Effendy, R; 2015).

Desa Wonokerso (termasuk kategori desa sulit air yang mayoritas warganya menggunakan air saluran irigasi untuk kebutuhan kehidupan mereka) mendapatkan hibah pembangunan pengadaan air bersih sebesar Rp.31.500.000,-. pada tahun 2010 lewat PNPM. Sejalan dengan ketentuan program, maka dibentuklah panitia pelaksana berupa Kelompok Swadaya Masyarakat (KSM) bernama Mangga Satu sebagai pelaksana proyek tersebut. Dengan semangat kebersamaan dan keswadayaan warga, proyek akhirnya dapat terwujud setelah menelan total dana sebesar Rp114.034.475,-. Dana tersebut digunakan untuk pembanguan sumur bor, pembelian pompa, meter air, instalasi listrik, pembelian tanah berukuran luas 6 meter persegi, pembangunan tandon beton permanen, pembelian meteran induk 3 unit. Warga sepakat untuk membentuk wadah HIPPAM Mangga Satu yang berlokasi di dusun Wonokerso sebagai lembaga yang bertanggungjawab atas pengelolaan layanan air bersih kepada -+ 290 konsumen rumah tangga.

Melihat kisah sukses HIPPAM Mangga Satu, proyek yang sama disepakati lewat Rembug Warga Desa LKM Karsa Santosa untuk dibangun di dusun Segenggeng tahun 2011. Sesuai dengan ketentuan PNPM-MP, proyek pembangunan tidak melebihi dari nominal Rp 50.000.000, makanya disiapkan dana sebesar Rp.47.500.000,-. KSM Mangga Dua sebagai pelaksana proyek pun dibentuk atas kesepakatan warga. Pengeboran air akhirnya terselesaikan dengan menghabiskan total dana sebesar Rp.72.000.000,-. Ini belum termasuk pembelian sebidang tanah berukuran 4x4 meter persegi karena memperoleh hibah dari warga bernama Suhadi yang sekaligus menjadi ketua KSM dan menjadi ketua HIPPAM Mangga Dua. Proses penyelesaian kegiatan dapat berlangsung setelah mendapatkan dukungan dana pinjaman dari dana hasil operasional HIPPAM Mangga Satu. Pada bulan Juli tahun 2011 sumur bor Mangga 2 sudah dapat beroperasi dan melayani rumah warga meski masih menggunakan tandon plastik. Setelah beroperasi enam bulan, lembaga layanan air bersih berbasis masyarakat ini telah dapat membangun tandon beton permanen dengan menghabiskan dana sebesar Rp 37.500.000,--dengan kapasitas tampung sebesar 15 ribu meter kubik. HIPPAM ini telah 


\section{Jurnal Komunikasi Nusantara}

e-ISSN. 2685-7650

Vol. 1 No. 2 (2019), pp 90-106

DOI: https://doi.org/10.33366/jkn.v1i2.25

mampu melayani 365 konsumen rumah tangga yang tersebar di sepuluh Rukun Tetangga alias dua Rukun Warga.

\section{Manajemen Outodidak Berbasis Modal Sosial}

Berbeda dengan program pemerintah yang mengkhususkan pada penyediaan air bersih berbasis masyarakat seperti PAMSIMAS dan WSLIC yang menyediakan fasilitas pendampingan tenaga pendamping mulai dari perencanaan, pelaksanaan, pengawasan baik kegiatan konstruksi, tata kelola kelembagaan dan keuangan, HIPPAM Mangga Satu dan Dua tidak mendapatkan fasilitas 'mewah' tersebut. Semua kegiatan tata kelola tersebut dilakukan secara mandiri, otodidak tanpa sentuhan tenaga professional bahkan bantuan dana dari pemerintah desa. Meski demikian, bermodalkan semangat sosial untuk memberikan layanan air bersih kepada warga, pengurus bekerja keras untuk mewujudkan cita-cita tersebut. Sebagai ketua, Suhadi yang telah menghibahkan sepetak tanah $4 \times 4$ meter persegi dibantu dengan pengurus lain harus standby 24 jam bekerja melayani keluhan kerusakan saluran jaringan pipa, memelihara fasilitas jaringan pipa, instalasi listrik, membersihkan tandon air, pompa air submersible dan detil teknis lainnya. Semua pekerjaan teknis tersebut dilakoni dengan trial and error dan pembelajaran sosial lewat jejaring sosial yang mereka miliki. Dari kerja jibaku ini, ia dan pengurus lainnya memperoleh insentif sebesar Rp 250.000 per-bulan dan baru dinaikkan menjadi Rp 500.000 awal tahun 2019. Salah satu kesalahan fatal dan sekarang mereka menyadari dan berusaha memperbaikinya adalah pemasangan ukuran pipa dari tandon air ke jaringan perpipaan; yang terpasang saat ini adalah pipa berukuran 2 dim sehingga memperlambat aliran air kepada rumah tangga pelanggan; seharusnya yang terpasang adalah pipa berukuran 4 dim sehingga aliran deras akan mengalir pada jaringan pipa.

Hal yang sama juga berlaku pada tata kelola administrasi dan pembukaan keuangan lembaga. Untuk mengelola pembayaran rekening pelanggan mereka hanya menggunakan perangkat lunak Microsoft exel sehingga sulit merekap jumlah konsumsi air secara periodik. Demikian juga halnya dengan laporan keuangan, pengurus harus bekerja keras untuk mencatat laporan keuangan secara elektronik. Transparansi laporan keuangan dan edukasi konservasi lingkungan hidup juga belum terlaksana berupa pelaksanaan pertemuan pelanggan. Tidak heran, kalau jumlah penunggak pembayaran rekening layanan air minum tetap membengkak dan belum dapat terselesaikan.

\section{Kinerja Sosial, Bukan Kinerja Kelembagaan Sebagai Ukuran Sukses Layanan}

Belum memiliki legalitas lembaga diperburuk dengan belum diperolehnya pengakuan politik dari dinas terkait terutama Dinas Pekerjaan Umum Perumahan Rakyat Pemkab Malang, memang menyulitkan operasi layanan terutama saat pemasangan pipa jaringan saat melintas dan di pinggir jalan raya. Tak ayal teguran dan peringatan harus mereka terima saat melakukan hal tersebut. Untuk menghindarinya, pemasangan dilakukan malam hari. Yang terpenting bagi mereka adalah pelayanan air bersih kepada pelanggan harus menjadi prioritas. Yang mendorong mereka berbuat demikian menurut Murta, J. (2014: 30) kuatnya rasa solidaritas sesama warga (sense of solidarity), serta komitmen untuk mencapai tujuan kesejahteraan bersama sosial (commitment for social purpose). Bermotif sosial, pengurus sepakat bentuk badan hukum lembaga adalah badan sosial, bukan badan usaha. Tidak heran, kalau mereka menolak dijadikan Badan Usaha Milik Desa yang lebih berientasi pada keuntungan. Ini karena usaha utama bisnis HIPPAM adalah layanan air berbasis masyarakat yang berorientasi pada layanan sosial yang bermuara kepada kesejahteraan bersama warga. Ini seperti tertuang dalam AD ART HIPPAM yang baru disahkan di Notaris Murfiatul Mufidah tahun 2019. 


\section{Jurnal Komunikasi Nusantara}

e-ISSN. 2685-7650

Vol. 1 No. 2 (2019), pp 90-106

DOI: https://doi.org/10.33366/jkn.v1i2.25

Melihat kinerja sosial handal HIPPAM warganya, Kepala Desa Naryadi (mantan Sekretaris Desa) yang baru terpilih telah memberikan kewenangan penuh pengelolaan sumur bor yang telah dibangun oleh Kementerian Pekerjaan Umum lima beberapa tahun silam kepada pengurus HIPPAM. Pengurus memandang sumur air tersebut memiliki potensi debit air tinggi. Makanya mereka berencana untuk menggabungkan jaringan pipanisasi air dengan jaringan pipa yang ada pada HIPPAM. Ini untuk mengantisipasi kalau ada terjadi kerusakan atau gangguan teknis pada sumur HIPPAM. Ini kemudian, akan dapat juga memperluas layanan air bersih kepada warga yang belum terlayani.

\section{HIPPAM Sebagai Organisasi Masyarakat Warga}

Secara struktural, HIPPAM yang awal mula berdirinya bernama Kelompok Swadaya Masyarak berada dalam kendali organisasi Lembaga Keswadayaan (LKM); sebuah organisasi bentukan PNPM-MP yang bertanggungjawab atas pengelolaan program. Sebagai program penanggulangan kemiskinan, program ini menyakini bahwa kemiskinan lebih disebabkan akibat terwujudnya nilai-nilai kebaikan moral dalam masyarakat yang kemudian bermuara pada tidak solidnya ikatan-ikatan sosial yang mengakibatkan tidak berfungsinya modal sosial. Pengurus LKM, makanya dipilih menggambarkan kepemimpinan kolektif warga masyarakat berlandaskan pada nilainilai moralitas. Pola kepemimpinan kolektif agar memastikan bahwa keputusan yang diambil secara telah mencerminkan nilai-nilai moral kebaikan yang bermuara pada keadilan sosial. Ini sekaligus untuk menghindari kepentingan politik sempit individu yang akan mengambil keuntungan politik. Mereka berada pada garda paling depan dalam memimpin organisasi masyarakat warga (Civil Society Organization) (PNPM-MP, Mengenal BKM/LKM: 2). Oleh karena, mereka juga pejuang nilai-nilai moralitas yang secara konsisten menerapkan dan mewujudkan nilai-nilai moral tersebut dalam semua rangkaian kegiatan program yang bertujuan untuk memulihkan kembali modal sosial masyarakat (PNPM-MP, Tugas dan Fungsi BKM/LKM; 24).

Nilai-nilai moral seperti yang diajarkan program telah terlaksana dalam pengelolaan HIPPAM. Hibah tanah seluas 4x4 meter persegi, insentif pengurus sebesar Rp 250.000 perbulan dan baru naik menjadi Rp 500.000 tahun 2019, etos kerja pengurus yang total alias all out 24 jam sehari dalam dalam memberikan layanan air bersih kepada warga dengan tanpa bimbingan teknis dari professional, semangat gotong royong dalam proses konstruksi tendon air, penetapan tariff harga layanan air bersih yang lebih murah dibandingkan dengan harga PDAM adalah bukti perwujudan dari nilai-nilai moral. Tidak hanya itu, kebijakan pengurus untuk menyumbangkan sebagaian keuntungan bersih dari jasa layanan kepada warga miskin serta kegiatan sosial dan perbaikan infrastruktur jalan desa (Effendy, R: 2014).

\section{Komunikasi Diskursus Kelestarian Lingkungan}

Wacana kelestarian lingkungan hidup telah menjadi perhatian utama pengurus LKM semenjak pendirian HIPPAM Satu tahun 2010. Untuk memelihara keberlangsungan cadangan air tanah, LKM telah mencanangkan program sebagai berikut; (1) Menanam pohon mangga di sepanjang jalan desa; (2) Gerakan "penghijauan rumah" dengan membuat sumur resapan air dan menanam pohon produktif di masing-masing rumah penduduk; (3) Kampanye "Hidup Sehat dan Bersih serta Ramah Lingkungan" bekerjasama dengan bidan desa dan Puskesmas Pakisaji untuk tidak membuang sampah atau limbah di saluran irigasi atau sungai; (4) Memberikan subsidi pembangunan 21 unit water closet bagi warga miskin yang dananya diperoleh dari keuntungan layanan HIPPAM plus dana Bantuan Langsung Masyarakat PNPM-MP; (5) Kampanye perilaku ramah lingkungan dengan 


\section{Jurnal Komunikasi Nusantara}

e-ISSN. 2685-7650

Vol. 1 No. 2 (2019), pp 90-106

DOI: https://doi.org/10.33366/jkn.v1i2.25

membuat unit usaha pengelolaan sampah berbasis masyarakat yang didahului dengan pelatihan "mengelola sampah menjadi berkah". Wacana tersebut seringkali diperbincangkan dalam pertemuan warga di balai desa dan pertemuan antar pribadi dan kelompok terutama antara pengurus dengan warga.

Wacana lain yang mulai berkembang dan menguat adalah pembatasan ketat alih fungsi lahan baik tanah persawahan maupun pekarangan untuk pembangunan sarana bisnis dan emukiman. Lokasi desa yang berada berdekatan dengan wilayah kota Malang plus dilewati jalan raya menuju kota Kepanjen ibu kota Kabupaten Malang menjadikannya sebagai tempat strategis untuk pembangunan infrastruktur ekonomi baik perumahan, pabrik dan pergudangan. Saat ini telah berdiri 3 kompleks perumahan di sekitar lokasi HIPPAM di Dusun Segenggeng. Bahkan akan dibangun 1 kompleks perumahan tepat di belakang lokasi sumur bor HIPPAM. Oleh karena itu, pengurus akan mengusulkan kepada Badan Permusyaratan Desa (BPD) untuk membuat Peraturan Desa untuk membatasi secara alih fungsi lahan secara ketat. Harus diatur dalam Raperdes tersebut kewajiban bagi pengembangan perumahan untuk membangun kawasan pemukiman ramah lingkungan dengan membangun sumur resapan dan tanaman pohon pada fasilitas sosial dan umum perumahan. Perdes konservasi lingkungan hidup ini penting demi menjadi ketersediaan cadangan baku air tanah untuk keberlangsungan layanan air minum.

\section{Literasi Ekologis, Lingkungan Hidup dan Etika dan Moralitas Tata Kelola Air}

Diskursus sosial tentang lingkungan hidup yang mengemuka dalam ruang publik lokal warga serta sikap perilaku mereka yang ramah terhadap lingkungan seperti tersebut diatas menggambarkan literasi ekologis dan lingkungan hidup yang mereka miliki. Mereka telah sadar dan prihatin tentang lingkungan beserta permasalahan yang menyertainya dan pengetahuan, ketrampilan serta motivasi untuk berupaya menyelesaikan permasalahan lingkungan saat ini dan mencegah terjadinya permasalahan lingkungan (McBride, 2013:3). Tapi urusan mengelola air berbasis masyarakat tidak hanya mencakup bagaimana menjaga dan memelihara kelestarian lingkungan hidup. Tapi juga meliputi pandangan hidup para informan terhadap esensi dan filosopi air serta paling penting adalah etika dan moralitas pengurus. Mengelola air menurut Wolf (2012: 73) terkait dengan dimensi spiritual, etika dan moralitas. Bukan lagi berurusan dengan teknis mengelola lembaga secara profesional dan rasional.

Berkaitan dengan hal tersebut, informan Adi Arif Rendra, SE, Ketua Asosiasi HIPPAM Kota Malang memandang bahwa pengelolaan air minum berbasis masyarakat harus didasarkan pada nilainilai kejujuran, kepedulian, dan keikhlasan. Nilai moral luhur ini harus menjiwai seluruh rangkaian kegiatan tata kelola layanan air minum oleh pengurus HIPPAM. "Hanya pengelola yang menerapkan nilai-nilai moral tersebut yang bisa menjamin keberlangsungan usaha jasa layanan air minum. Dengan demikian, HIPPAM dipastikan dapat menumbuhkembangkan modal sosial masyarakat seperti kerukukan, kepedulian yang akan bermuara pada kesejahteraan warga. Singkat kata, moralitas pengurus akan merukunkan warga. Kalau tidak demikian, HIPPAM justru akan mendatangkan mala petaka bagi warga akibat ketidakjujuran dan perilaku koruptif pengurus. Ialantas memaparkan kisah nyata inspiratif tentang usaha pengeboran air di sebuah kelurahan di Kota Malang. Al kisah, seorang warga ingin menghibahkan sepetak tanah untuk usaha layanan air minum. Begitu melihat air tanah yang menyembur melimpah ruah setelah dibor, niat untuk menghibahkan tanahnya pun diurungkan seyampang terpikir olehnya untuk mengelola air tersebut untuk keuntungan ekonomi pribadinya. Niat membatalkan hibah tanah yang terucapkan tersebut membuat air tanah dari sumur artesis tersebut seketika surut dan perlahan menghilang. Melihat suasana tersebut, dia lantas kembali berniat 


\section{Jurnal Komunikasi Nusantara}

e-ISSN. 2685-7650

Vol. 1 No. 2 (2019), pp 90-106

DOI: https://doi.org/10.33366/jkn.v1i2.25

menghibahkan kembali sepetak tanahnya. Khawatir akan mengulangi tindakan yang sama, niat tersebut pun ditolak oleh Lurah. Tanah tersebut akhirnya dibeli oleh Kelurahan. Pengeboran air tanah pun dilanjutkan. Ajaibnya, air tanah kembali dapat berhasil keluar muncul dari dalam tanah.

Kisah tersebut semakin menyakinkannya bahwa pengelolaan air HIPPAM harus berlandaskan atas nilai-nilai moral demi kebaikan bersama warga, bukan untuk mencari keuntungan semata. "Saya mewajibkan kepada seluruh pengelola HIPPAM kota Malang agar menyisihkan sebagaian pendapatannya untuk dialokasikan untuk menyantuni fakir miskin dan yatim piatu di sekitar wilayah layanan. Hanya dengan cara seperti ini, pengelolaan air minum oleh HIPPAM akan dapat berkelanjutan. Ini karena kalau terjadi salah kelola dan HIPPAM bangkrut, maka semua aset lembaga akan diambil alih oleh negara akibat ketidakmampuan masyarakat dalam mengelola jasa layanan air minum. Ini sesuai dengan aturan perundangan yang berlaku," tegasnya. Untuk itu, tambahnya bentuk badan hukum yang tepat untuk HIPPAM adalah himpunan atau perkumpulan, bukan badan usaha seperti Badan Usaha Milik Desa (Bumdesa).

\section{Hak Rakyat Untuk Mengelola Sumber Daya Air}

Sumber daya alam nasional yang melimpah dan berada di seluruh tanah air memang harus dikuasai oleh negara yang bertujuan untuk memaksimalkan pemanfaatannya untuk kemakmuran rakyat. Selain swasta, rakyat juga mesti dilibatkan dalam mengelola sumber daya alam, dalam hal adalah sumber daya air. Konsep co-management atau pengelolaan sumber alam berbasis masyarakat (Community-based natural resource management) berarti berbagi pengelolaan atas sumber daya antara negara dengan masyarakat. Di sini adalah jaminan pengelolaan sumber daya yang berkelanjutan. Seperti ditegaskan Brosius (1998:158), hal ini karena warga masyarakat lokal memiliki komitmen lebih besar terhadap pengelolaan sumber daya alam yang berkelanjutan daripada negara dan perusahaan; mereka lebih sadar dan mengetahui tentang kompleksitas proses dan praktik ekologi lokal ; mereka lebih mampu untuk dapat mengelola sumber daya tersebut secara lebih efektif lewat nilai-nilai dan kearifan lokal mereka. Sumber daya air makanya merupakan sumber daya milik masyarakat yang harus dikelola sedemikian rupa agar manfaatnya dapat dirasakan oleh sebagaian besar warga masyarkat "water is a community resource and that water ought to be governed in the "public interest in accordance with the righteous principles of the greatest good to the greatest number for the longest time," (Schmidt, 2014 : 227). Pengelolaan air secara kolektif oleh masyarakat tidak tepat tapi juga keniscayaan. Bakker, K. (2007: 441) memaparkan ada tiga alasan Pertama, pengelolaan layanan air oleh negara atau perusahaan dimungkinkan akan terjadi kegagalan. Keterlibatan masyarakat akan bisa membantu pengelolaan air yang berkelanjutan. Kedua, air memiliki dimensi kultural dan spiritual yang biasanya terkait erat dengan pranata dan norma warga lokal yang sulit diterapkan oleh negara dan perusahaan swasta. Ketiga, air merupakan sumber daya mengalir milik warga lokal yang penggunaan dan pemanfaatannya akan berdampak terhadap mereka secara langsung. Lewat semangat sosial kebersamaan yang dimiliki, maka akan dapat dijamin upaya perlindungan dan pemeliharaan keberlangsungan pengelolaan sumber daya tersebut.

Wacana dan sikap informan tentang air dan tata kelola air berbasis masyarakat seperti dipaparkan di atas sangat bertentangn dengan isi dengan UU No 172019 Tentang Sumber Daya. Hal tersebut melambangkan perang ideologi antara penganut air sebagai barang milik bersama atau commons melawan mereka yang memandang air sebagai barang komoditas; air sebagai barang dagangan melawan air sebagai hak asasi manusia. UU tersebut menandai era swastanisasi air yang dipastikan akan mengancam keberlangsungan sistem air berbasis masyarakat (AlAfghani:2018). UU yang ditengarai mempersulit pengakuan Masyarakat Hukum Adat telah meneoliberalisasi alam 


\section{Jurnal Komunikasi Nusantara}

e-ISSN. 2685-7650

Vol. 1 No. 2 (2019), pp 90-106

DOI: https://doi.org/10.33366/jkn.v1i2.25

(neoliberalizing Nature) dengan utama mengubah sumber daya alam dari kepemilikan bersama menjadi barang dagang (Bakker :2007 :433). Kekuatan kapitalis internasional Bank Dunia papar Yunita (2014) ikut terlibat dalam proses privatisasi ini lewat rencana restrukturisasi pengelolaan air atau WATSAL (Water Restructuring Adjustment Loan). Hal ini diperkuat dengan hasil penelitian tahun 2003 oleh organisasi International Consortium of Investigative Journalist yang menemukan bahwa bahwa mayoritas pinjaman Bank Dunia dalam lima tahun terakhir telah mempersyaratkan adanya pengalihan sistem publik kepada swasta (Barlow, $2002: 10$ ).

Debat antara kedua kubu tersebut menurut Bakker (2007:441) dapat dijelaskan sebagai berikut. Pro commons air menganggap air sebagai barang milik pubik, sementara pro komoditas memandangnya sebagai barang bernilai ekonomi. Harga lebih ditentukan oleh biaya pemulihan penuh (full cost recovery), sementara lawannya melihat harus murah sebab ia merupakan bentuk layanan publik pemerintah terhadap masyarakat. Pemerintah harus menguasai dan mengendalikan tata kelola air, sementara kubu bersebarangan memandang agar pasar sebagai pengawas dan pengontrol. Pengelolaan sumber daya harus diarahkan untuk mencapai keadilan dan kehidupan yang adil, sementara kubu yang lain disasarkan untuk mencapai efisiensi dan keterjaminan sumber daya alam. Pengelola sumber daya air adalah masyarakat, sementara kubu yang lain memandang pasar sebagai pengelolanya. Pro kontra tersebut secara ringkas dapat dilihat berikut ini.

Tabel 1: Debat Commons melawan Commodity

\begin{tabular}{|l|l|l|}
\hline \multicolumn{1}{|c|}{ Hal } & \multicolumn{1}{c|}{ Commons } & \multicolumn{1}{c|}{ Commodity } \\
\hline Definisi & Barang milik public & Barang bernilai ekonomis \\
\hline Harga & Murah & $\begin{array}{l}\text { Mahal (menutupi biaya pemulihan) -full } \\
\text { cost recovery }\end{array}$ \\
\hline Regulasi & Komando dan Kontrol pemerintah & Berdasarkan permintaan pasar \\
\hline Tujuan & Keadilan dan kehidupan yang adil & Efisiensi dan keterjaminan air \\
\hline Pengelola & Masyarakat & Pasar (swasta) \\
\hline
\end{tabular}

Sumber: Bakker, K. (2007). The "Commons" Versus the "Commodity": Alter-globalization, Anti-

Privatization and the Human Right to Water in the Global South. Antipode, 39(3), 430-455.

\section{Kesimpulan}

Berdasarkan paparan sebelumnya dapat disimpulkan beberapa hal sebagai berikut. Air saat telah berubah menjadi emas biru (blue gold) akibat tingginya permintaan terhadapnya. Konsekwensinya harga air semakin hari semakin mahal. Hal ini lebih disebabkan akibat adanya tekanan kekuatan internasional yang dipastikan bertentangan dengan nilai-nilai sosial dan filosofi perundangan sebagaimana diamanatkan oleh UU Dasar Republik Indonesia utamanya pasal 33. Hak rakyat atas air yang merupakan hak asasi manusia yang diwujudkan dalam sistem penyediaan air minum berbasis masyarakat berupa HIPPAM pun terancam keberlanjutan operasinya akibat pemberlakuan UU ini. Sejarah telah mencatat bahwa upaya privatisasi air ini telah pernah mengalami kegagalan total dengan Putusan Mahkamah Konstitusi yang membatalkan secara keseluruhan UU No 42007 Tentang Sumber Daya Air.

HIPPAM Mangga Dua yang dilahirkan dari 'rahim' PNPM-MP yang sarat akan nilai-nilai moralitas dalam pembangunan berbasis masyarakat telah menerapkan prinsip nilai moralitas tersebut dalam mengelolan layanan air. Semangat melayani distribusi air minum secara total kepada warga miskin utamanya telah diwujudkan oleh para pengurus. Keikhlasan dan dedikasi mereka dalam 


\section{Jurnal Komunikasi Nusantara}

e-ISSN. 2685-7650

Vol. 1 No. 2 (2019), pp 90-106

DOI: https://doi.org/10.33366/jkn.v1i2.25

pelayanan air begitu kental yang ditunjukkan dengan 24 jam kerja pelayanan serta menangani berbagai teknis. Bagi mereka air bukan sekedar barang publik tapi memiliki dimensi sosial dan spiritual. Air yang dikelola harus dipastikan betul-betul bermanfaat bagi seluruh warga, bukan sebagai sarana untuk mengumpulkan keuntungan ekonomi. Mereka, makanya menolak keras wacana untuk dijadikan badan usaha milik desa. Air bagi mereka, makanya merupakan modal sosial yang mengguyubakan dan merukunkan sesama warga masyarakat. Tidak hanya itu, air juga bagi mereka harus diabdikan untuk kebaikan dan kesejahteraan sosial warga utamanya mereka yang tidak mampu. Tidak heran, kalau keuntungan bersih hasil jasa pengelolaan sumber daya air disumbangkan untuk pembangunan infrastruktur jalan, renovasi rumah warga miskin, pembangunan Taman Bacaan Masyarakat, pembangunan water closet serta kepentingan sosial yang lain.

Tindakan kebaikan tersebut juga mengkomunikasikan sebuah pesan bahwa air itu harus diperlakukan untuk kebaikan sosial. Tidak hanya itu, diskursus kelestarian lingkungan hidup, perilaku hidup sehat dan bersih sering kali mereka komunikasikan dalam ruang publik lokal yang tersedia seperti dalam rapat pertemuan desa (Rembug Warta Tahuan) dan perbincingan antara sesama pengurus. Komunikasi lingkungan yang terlaksana dan akan terus diupayakan demi keberlangsungan ketersediaan cadangan air tanah. Bahkan ada wacana untuk memohonkan kepada pemerintah desa dan BPD untuk menerbitkan Peraturan Desa tentang konservasi lingkungan hidup dan perilaku hidup sehat.

Acknowledgement: Artikel ini dapat tersusun sebagai bagian dari Skema Pengabdian Kepada Masyarakat Program Kemitraan Masyarakat Direktorat Riset dan Pengabdian Masyarakat Direktorat Jenderal Penguatan Riset dan Pengembangan Kementerian Riset, Teknologi dan Pendidikan Tinggi tahun 2019.

\section{Daftar Pustaka}

Al'Afghani, M.M.; Kohlitz, J. and Willetts, J. (2019). Not built to last: Improving legal and Institutional Arrangements for Community-Based Water And Sanitation Service Delivery In Indonesia. Water Alternatives, 12 (1), 285-303 diakses pada http://www.wateralternatives.org/index.php/alldoc/for-authors/490-a12-1-16/file.

Ardian, H.Y. (2019). Kajian Teori Komunikasi Lingkungan Dalam Penelitian Pengelolaan Sumber Daya Alam. Jurnal Perspektif Komunikasi, 3 (1). diakses pada https://jurnal.umj.ac.id/index.php/perspektif/article/download/3894/2891

Bakti, Iriana., H. H., Budiana, H. R., Puspitasari, L. P. (2017). Pemberdayaan Pranata Sosial Melalui Komunikasi Lingkungan: Menakar Pelibatan Peran Perempuan Dalam Mitigasi Banjir Citarum. Jurnal Kawistara. 7 (1). diakses pada https://doi.org/10.22146/kawistara.24313 https://jurnal.ugm.ac.id/kawistara/article/download/24313/17328

Bartholomew, A. (2010). The Spiritual Life of Water: Its Power and Purpose. Totonto, Canada: Park Street Press.

Barlow, M., Clarke, T. (2002). Blue Gold: The Fight to Stop The Corporate Theft of the World's Water. New York, USA: The New Press. 


\section{Jurnal Komunikasi Nusantara}

e-ISSN. 2685-7650

Vol. 1 No. 2 (2019), pp 90-106

DOI: https://doi.org/10.33366/jkn.v1i2.25

Bakker, K. (2007). The "Commons" Versus the "Commodity": Alter-globalization, Anti-Privatization and the Human Right to Water in the Global South. Antipode, 39(3), 430-455. Diakses pada https://doi.org/10.1111/j.1467-8330.2007.00534.x

Brosius, J. P., Tsing, A. L., \& Zerner, C. (1998). Representing Communities: Histories and Politics Of Community-Based Natural Resource Management. Society \& Natural Resources, 11(2), 157168. https://doi.org/10.1080/08941929809381069.

Center for Policy Regulation and Governance (CPRG). (2018). Kertas Posisi Masukan Jejaring AMPL Kepada Dewan Perwakilan Rakyat Republik Indonesia Perihal Rancangan UndangUndang Sumber Daya Air (RUU SDA), diakses pada https://cloud.crpg.info/docs/KertasPosisiRUUSDA.pdf

Capra, F. (2007). Sustainable Living, Ecological Literacy, and the Breath of Life. Canadian Journal of Environmental Education, 12, 9-18 diakses pada https://cjee.lakeheadu.ca/article/viewFile/624/507

Capra, F. (1994). Ecology and community. Berkeley, California, USA: Center for Ecoliteracy.

Capra, F. (1975). The Tao of Physics: An Exploration of the Parallels Between Modern Physics and Eastern Mysticism. Colorado, USA: Shambhala Publications, Inc.

Effendy, R. (2015). 'The Moral Values as The Foundation for Sustainable Community Development: A Review Of The Indonesia Government-Sponsored National Program for Community Empowerment Urban Self Reliance Project (PNPM MP). Journal of Economics and Sustainable Development 6 (7), 1-22.

Effendy, R. (2014). Sustaining Community Welfare Through Good Water Governance: A Study of Integrated Water Resources Management Implementation by Water Consumers' Association (HIPPAM / Himpunan Penduduk Pengguna Air Minum) at Wonokerso Village Pakisaji Subdistrict Malang Regency East Java Indonesia, Proceeding International Symposium on Sustainable Regional Development. Universitas Merdeka Malang

Foulger, D. (2004). An Ecological Model of The Communication Process. Paper presented at the international communication spring meeting, New York diakses pada http://davis.foulger.info/papers/ecologicalModelOfCommunication.htm

Hardin, G. (1968). The Tragedy of the Commons, 162 (3859), 1243-1248,.diakses pada http://doi.org/10.1126/science.162.3859.1243

Jurin, R. R., Roush, D., Danter., Jeff, (2010). Environmental Communication: Skills and Principles for Natural Resource; Managers, Scientists, and Engineers, Second Edition. London New York, USA: Springer Dordrecht Heidelberg.

Lestari, P., Paripurno, E. T., Kusumayudha, S. B., Ramadhaniyanto, B. (2016). Komunikasi Lingkungan Untuk Mitigasi Bencana Erupsi Gunung Sinabung. Jurnal ASPIKOM, 3 (1), 5664.

Lie, R., \& Servaes, J. (2015). Disciplines in the Field of Communication for Development and Social Change. Communication Theory, 25(2), 244-258. https://doi.org/10.1111/comt.12065

McBride B. B., C. A. Brewer, A. R. Berkowitz, and W. T. Borrie. (2013). Environmental Literacy, Ecological Literacy, Ecoliteracy: What Do We Mean And How Did We Get Here? Ecosphere, 4(5), 67. http://dx.doi.org/10.1890/ES13-00075.1

Murta, J. and Willetts, J. (2014). 'Incentives for Enterprise Engagement In Indonesia', Private And Social Enterprise Engagement In Water And Sanitation For The Poor - Working Paper 2a, Institute for Sustainable Futures, University of Technology, Sydney. 


\section{Jurnal Komunikasi Nusantara}

e-ISSN. 2685-7650

Vol. 1 No. 2 (2019), pp 90-106

DOI: https://doi.org/10.33366/jkn.v1i2.25

Pezzullo, Phaedra C., Cox, Robert, 2018, Environmental Communication and the Public Sphere, 5th Edition SAGE , Los Angeles, California, USA

PNPM-MP, tanpa tahun, Mengenal BKM/LKM; Modul Khusus Lurah/Kades; Pelatihan Dasar, Direktorat Jenderal Cipta Karya, Departemen Pekerjaan Umum, Jakarta

PNPM-MP, tanpa tahun, Tugas dan Fungsi BKM/LKM; Modul Khusus Lurah/Kades; Pelatihan Dasar, Direktorat Jenderal Cipta Karya, Departemen Pekerjaan Umum, Jakarta

Schmidt, J.J. (2014). Historicising the Hydrosocial Cycle, Water Alternatives 7(1): 220-234 diakses http://www.water-alternatives.org/index.php/alldoc/articles/vol7/v7issue1/242-a7-1-13/file

Swarnawati, A. (2018). Komunikasi Lingkungan Dalam Program Konservasi Laut Di Taman Nasional Kepulauan Seribu, Tesis Sekolah Pascasarjana Institut Pertanian Bogor

The International Environmental Association (THEIECA). (2008). Environmental Communication: What it is and Why it Matters, diakses pada https://theieca.org/sites/default/files/optp/\%20OPTP\%231-EC_What_and_Why.pdf

Wahyudin, U. (2017). Strategi Komunikasi Lingkungan Dalam Membangun Kepedulian Masyarakat Terhadap Lingkungan. Jurnal Common, 1 (2). diakses pada https://ojs.unikom.ac.id/index.php/common/article/download/576/425/

Wolf, A. T. (2012). Spiritual Understandings of Conflict and Transformation and Their Contribution to Water Dialogue. Water Policy, 14 (S1), 73-88. https://doi.org/10.2166/wp.2012.010

Yunita, T. R., Harto, S. (2014). Peranan Bank Dunia Terhadap Privatisasi Sektor Air Di Indonesia Pada Tahun 1998-2010, Jurnal Online Mahasiswa Fakultas Ilmu Sosial dan Ilmu Politik Universitas Riau diakses pada https://jom.unri.ac.id/index.php/JOMFSIP/article/download/2222/2164

\section{Artikel Berita Media Online}

Al Afghani, M. M. (2018). Konsepsi 'Swasta' pada RUU SDA Ancam Sistem Air Berbasis Masyarakat, 2 Agustus 2018 diakses pada https://tirto.id/konsepsi-swasta-pada-ruu-sda-ancamsistem-air-berbasis-masyarakat-cQfT

CNN Indonesia. (2019). Walhi soal UU SDA: Kedok Investasi Dalih Kepentingan Rakyat, diakses pada https://www.cnnindonesia.com/nasional/20190919202330-20-432120/walhi-soal-uu-sdakedok-investasi-dalih-kepentingan-rakyat

Harian Kompas. (2019). Sempat Ditunda, DPR Akhirnya Sahkan RUU Sumber Daya Air Jadi UU, diakses pada https://nasional.kompas.com/read/2019/09/17/19450631/sempat-ditunda-dprakhirnya-sahkan-ruu-sumber-daya-air-jadi-uu?page=all

Inews. (2019). UU SDA Disahkan, Gunakan Air untuk Usaha Tanpa Izin Bisa Didenda Rp5 Miliar, diakses pada https://www.inews.id/news/nasional/uu-sda-disahkan-gunakan-air-untuk-usahatanpa-izin-bisa-didenda-rp5-miliar/all

Kumparan News. (2019). Walhi Gugat UU Sumber Daya Air yang Baru Disahkan, diakses pada https://kumparan.com/kumparannews/walhi-gugat-uu-sumber-daya-air-yang-baru-disahkan1rtZJSur3Md

Koran Tempo. (2019). RUU Sumber Daya Air Disahkan, Walhi: Swastanisasi Terselubung, diakses pada https://nasional.tempo.co/read/1250545/ruu-sumber-daya-air-disahkan-walhi-swastanisasiterselubung/full\&view=ok 


\section{Jurnal Komunikasi Nusantara}

e-ISSN. 2685-7650

Vol. 1 No. 2 (2019), pp 90-106

DOI: https://doi.org/10.33366/jkn.v1i2.25

Tirto.id. (2019). Demi Investasi, RUU Sumber Daya Air Abaikan Konservasi, diakses pada https://tirto.id/demi-investasi-ruu-sumber-daya-air-abaikan-konservasi-ehki 